\title{
ARAHAN KEBIJAKAN MITIGASI PADA ZONA RAWAN BANJIR KABUPATEN LIMAPULUH KOTA, PROVINSI SUMATERA BARAT
}

\author{
Mitigation Policy Directions In Flood Hazard Zone At Limapuluh Kota District, West \\ Sumatra Province
}

\author{
Iswandi Umar ${ }^{\mathrm{a}}$, Indang Dewata ${ }^{\mathrm{b}}$ \\ ${ }^{a}$ Jurusan Geografi, Fakultas Ilmu Sosial, Universitas Negeri Padang, Jln. Prof. Dr. Hamka Airtawar Padang, \\ Padang25475_iswandi_u@yahoo.com \\ ${ }^{b}$ Pusat Penelitian Kependudukan dan Lingkungan Hidup (PPKLH) Universitas Negeri Padang, Jln. Prof. Dr. \\ Hamka Airtawar Padang, Padang 25475
}

\begin{abstract}
Indonesia is a country that has a wet tropical climate, so that about $60 \%$ of the cities in Indonesia is very a hazard to flood. The floods have caused many losses to humans. The purpose of this study is determine the direction of development policy mitigation of flood hazard zones in Limapuluh Kota District, by using GIS analysis with the overlay technique. The indicators used to determine the flood hazard zones are rainfall, slope, landform, soil type, geology, elevation, and land use. Mitigation policy directives using AHP analysis involving 15 experts with conservation criteria, regulations, community capacity. The results showed $6,2 \%$ is a very flood zone. Three main landing to reduce the impact of floods is disaster education, improved socialization in flood hazard zones, and planning of based spatial disaster.
\end{abstract}

Keywords: Flood, hazard, policy directives.

(Diterima: 22-05-2017; Disetujui: 08-11-2017)

\section{Pendahuluan}

\subsection{Latar belakang}

Kehidupan manusia tidak bisa terlepas dari pemanfaatan lahan, lahan dan tanah merupakan sumberdaya penting bagi kehidupan manusia. Semakin banyak jumlah penduduk pada suatu wilayah, maka tekanan terhadap lahan semakin meningkat, dan akan menimbulkan konflik kepentingan dalam pemanfaatan lahan. Sadyohutomo (2008) mengungkapkan bahwa peningkatan jumlah penduduk akan mendorong peningkatan kebutuhan akan penggunaan lahan. Luas lahan yang dapat digunakan untuk mendukung kehidupan relatif tetap dan bersifat terbatas. Sebagai akibatnya, akan terjadi persaingan penggunan lahan dan pada akhirnya akan terjadi konflik antarpengguna. Karmakar et al. (2010) dan Kodoatie (2013) dampak perubahan penggunaan lahan menjadi lahan terbangun adalah terjadinya peningkatan bencana banjir.

Banjir dapat didefinisikan sebagai aliran air di permukaan tanah yang relatif tinggi dan tidak dapat ditampung oleh saluran drainase atau sungai, sehingga melampaui badan sungai serta menimbulkan genangan atau aliran dalam jumlah yang melebihi normal dan mengakibatkan kerugian pada manusia (BNPB 2012 dan Wardhono et al. 2012). Menurut Asdak (1995), Bechtol dan Laurian (2005), bahwa banjir dipengaruhi oleh tiga faktor, yakni meteorologi, karakteristik DAS, dan perilaku manusia. Mudelsee et al. (2003), Popovska et al. (2010), Wardhono et al. (2012), dan Umar (2016a) menyatakan peningkatan intensitas curah hujan dapat mendorong terjadinya banjir, peningkatan curah hujan dipengaruhi oleh faktor peningkatan suhu secara global yang berdampak terhadap percepatan siklus hidrologi. Kodoatie (2013) dan Umar et al. (2016b) banjir dapat dipengaruhi oleh karakteristik daerah aliran sungai (DAS) berupa bentuklahan, elevasi, jenis tanah, dan kemiringan lereng. Selain itu, Kodra dan Syaurkani (2004), Pribadi et al. (2006), Kodoatie (2013), dan Yüksek et al. (2013) menyatakan bahwa perilaku masyarakat dalam pemanfaatan lahan dapat memperburuk terjadinya bencana banjir.

UU No 24 Tahun 2007 tentang Penanggulangan Bencana dan BNPB (2012) menjelaskan bahwa rawan bencana merupakan kondisi atau karakteristik geologis, biologis, hidrologis, klimatologis, geografis, sosial, budaya, politik, ekonomi, dan teknologi pada suatu kawasan untuk jangka waktu tertentu yang mengurangi kemampuan untuk mencegah, meredam, mencapai kesiapan, dan mengurangi kemampuan untuk menanggapi dampak buruk bahaya tertentu. Upaya yang dapat dilakukan dalam rangka mencegah atau meminimalisis dampak buruk dari bencana banjir yakni melakukan mitigasi.

BPBD Kabupaten Limapuluh Kota mencatat adanya terjadi peningkatan bencana banjir baik dari frekuansi maupuan luasan yang terkena dampak pada periode 2010-2017. Salah satu bentuk mitigasi yang dapat dilakukan untuk meminimalisir dampak risiko banjir dengan cara menentukan arahan kebijakan mitigasi pada zona rawan banjir di Kabupaten Limapuluh Kota. 


\subsection{Tujuan Penelitian}

Berdasarkan latar belakang dikemukakan diatas maka tujuan penelitian ini untuk menentukan arahan kebijakan mitigasi pada zona rawan banjir di Kabupaten Limapuluh Kota, Provinsi Sumatera Barat.

\section{Metode Penelitian}

\subsection{Lokasi dan Waktu Penelitian}

Penelitian ini dilaksanakan pada Kabupaten Limapuluh Kota Provinsi Sumatera Barat. Secara geografis Kabupaten Limapuluh Kota terletak pada bujur $100^{0} 15^{\prime}$ BT - $100^{0} 53^{\prime}$ BT dan lintang $0^{0} 25^{\prime} \mathrm{LU}$ $0^{0} 25^{\prime}$ 'LS. Waktu penelitian dilaksanakan pada Maret 2017. Gambar 1 merupakan lokasi penelitian secara administratif.

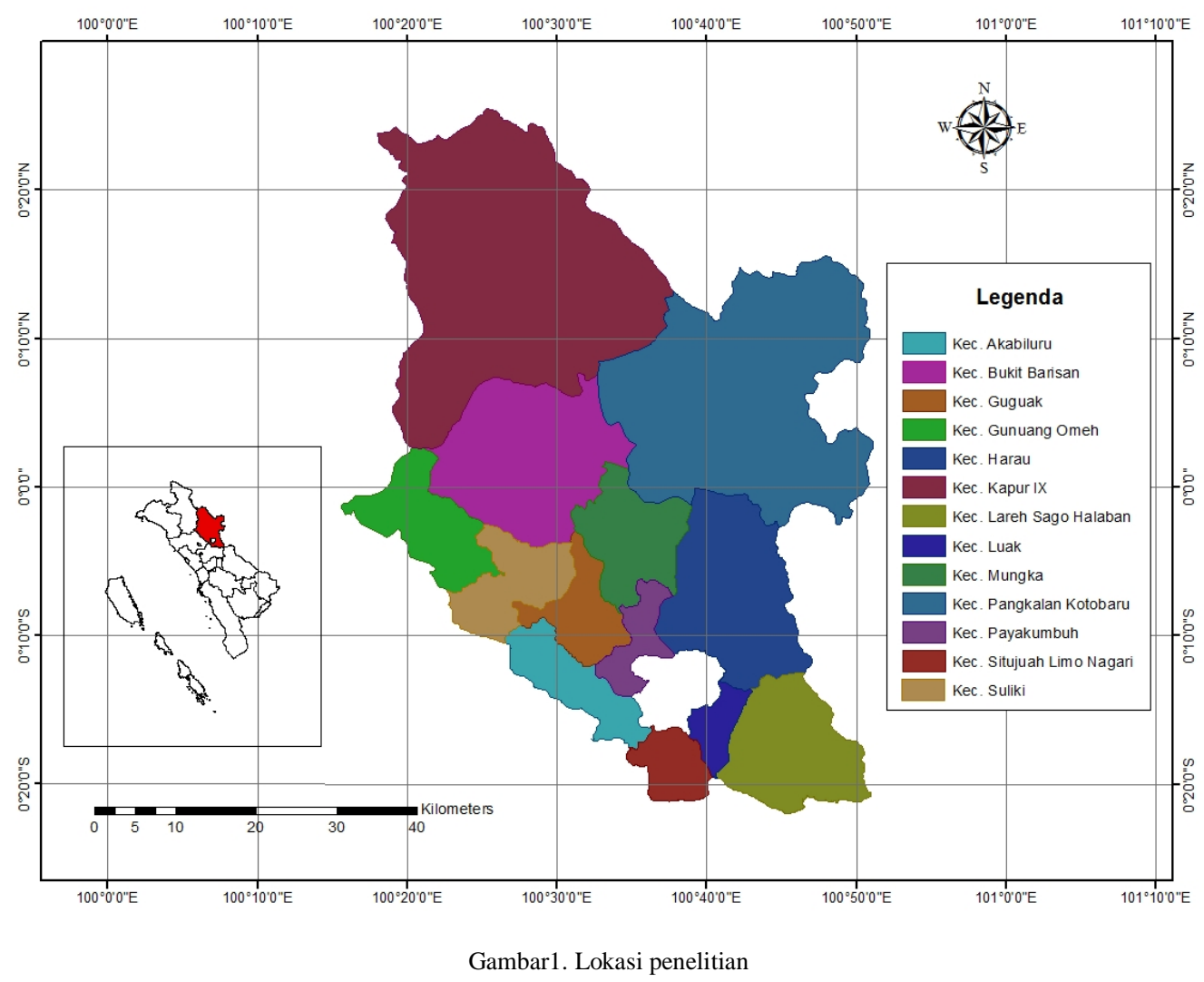

\subsection{Alat dan Bahan Penelitian}

Penelitian ini membutuhkan beberapa alat dan bahan yang akan digunakan untuk model kebijakan pengelolaan zona rawan banjir paba Kabupaten Limapuluh Kota. Alat yang dibutuhkan dalam penelitian ini dapat disajikan sebagai berikut:

a) GPS untuk menentukan kordinar lokasi rawan banjir.

b) Komputer dengan software yang digunakan untuk analisis antara lain program Art GIS 10.1 dan program Expert Choice 2011. Program Art GIS 10.1 digunakan untuk analisis penentuan zona rawan banjir. Program Expert Choice 2011 digunakan untuk menentukan arahan kebijakan kerawan banjir.

c) Alat tulis dan kertas.

Selanjutnya, bahan yang digunakan untuk penentuan model kebijakan pengelolaan zona rawan banjir paba Kabupaten Limapuluh Kota dapat disajikan pada Tabel 1.
Tabel 1. Bahan yang digunakan dalam penelitian

\begin{tabular}{|c|c|c|}
\hline No & Jenis & Sumber \\
\hline 1 & $\begin{array}{c}\text { Data curah hujan periode } \\
1975-2017\end{array}$ & BMKG Sicincin \\
\hline 2 & Elevasi dan lereng & $\begin{array}{l}\text { Citra Shuttle Radar } \\
\text { Topography Mission } \\
\text { (SRTM) } 1 \text { Arc Second }\end{array}$ \\
\hline 3 & Penggunaan lahan & $\begin{array}{c}\text { Citra Landsat ETM+7 } \\
2016\end{array}$ \\
\hline 4 & $\begin{array}{c}\text { Jenis tanah skala } 1: \\
250.000\end{array}$ & $\begin{array}{c}\text { Pusat Penelitian Tanah } \\
\text { Bogor tahun } 1990\end{array}$ \\
\hline 5 & $\begin{array}{c}\text { Bentuklahan skala 1: } \\
250.000\end{array}$ & RePPProT tahun 1990 \\
\hline 6 & Geologi skala $1: 250.000$ & $\begin{array}{c}\text { Badan Geologi } \\
\text { Bandung tahun } 2007\end{array}$ \\
\hline
\end{tabular}

\subsection{Prosedur Penelitian}

Deliniasi kawasan rawan banjir ditentukan dengan menggunakan tujuh indikator, yaitu: lereng, elevasi, penggunaan lahan, curah hujan, bentuklahan, jenis tanah, dan geologi. Peta lereng dan elevasi dihasilkan dari Digital Evation Model (DEM) menggunakan citra Shuttle Radar Topography Mission (SRTM) 1 Arc 
Second. Peta curah hujan diperoleh dari interpolasi data curah hujan BMKG Sicin periode 1975-2017 pada lima stasiun curah hujan di Kabupaten Limapuluh Kota yang membentuk garis isohyet. Peta jenis tanah diturunkan dari Peta Jenis Tanah tahun 1990 skala 1:250,000. Bentuklahan dihasilkan dari RePPProT tahun 1990 skala 1:250,000. Peta geologi diturunkan dari skala $1: 250,000$ yang dihasilkan oleh Badan Geologi Bandung tahun 2007. Selanjutnya peta penggunaan lahan Kabupaten Limapuluh Kota dihasilkan dari interpretasi citra Landsat $7+$ ETM tahun 2016 dan dikoreksi dengan citra Quick Bird $0.65 \mathrm{~m}$ tahun 2010. Untuk dapat melakukan overlay, maka dilakukan penyamaan skala peta yaitu 1:50,000. Tabel 2 disajikan indikator penentuan zona rawan banjir.

Hasil perkalian antara bobot dengan harkat akan diperoleh skor diperoleh masing-masing indikator. Untuk menentukan zonasi rawan digunakan Persamaan 1. Hasil analisis menghasilkan total skor tertinggi sebesar 440 dan total skor terendah sebesar 85, maka dengan tiga kelompok kelas diperoleh interval sebesar 118 seperti yang disajikan pada Tabel 3.

dimana :

$$
I=\frac{c-b}{k}
$$

$$
\begin{aligned}
& I=\text { besar jarak interval kelas } \\
& \mathrm{c}=\text { jumlah skor tertinggi } \\
& \mathrm{b}=\text { jumlah skor terendah } \\
& \mathrm{k}=\text { jumlah kelas yang diinginkan }
\end{aligned}
$$

Untuk menentukan arahan kebijkan mitigasiditentukan berdasarkan pendapat pakar dengan menggunakan metode AHP (Analytical Hierarchy Process). Pakar akan menentukan penilaian yang berdasarkan skala 1 sampai 9 secara perbandingan berpasangan (pairwise comparision). Menurut Saaty (1983), Marimin dan Maghfiroh (2010) skala 1 sampai 9. Nilai dan definisi pendapat pakar dalam skala perbandingan ada pada Tabel 4.

Pakar yang digunakan untuk penentuan arahan kebijakan mitigasi berasal dari Perguruan Tinggi, LSM, Bappeda Kab. Limapuluh Kota, Tokoh masyarakat, Pusat Kajian Kebencanaan UNP, dan BPBD Kab. Limapuluh Kota. Jumlahpakar yang digunakanuntukpenentuanarahan kebijakan mitigasi pada zona rawan banjir sebanyak 25 orang pakar. Struktur hierarki arahan kebijakan mitigasi disajikan

\begin{tabular}{|c|c|c|c|}
\hline Nilai & \multicolumn{3}{|l|}{ Keterangan } \\
\hline 1 & \multicolumn{3}{|l|}{ A sama penting dengan $\mathrm{B}$} \\
\hline 3 & \multicolumn{3}{|l|}{ A sedikit lebih penting dari B } \\
\hline 5 & \multicolumn{3}{|l|}{ A jelas lebih penting dari B } \\
\hline 7 & \multicolumn{3}{|c|}{ A sangat jelas lebih penting dari B } \\
\hline 9 & \multicolumn{3}{|c|}{ A mutlak lebih penting dari B } \\
\hline $\begin{array}{c}2,4,6 \\
8\end{array}$ & \multicolumn{3}{|c|}{$\begin{array}{l}\text { Apabila ragu-ragu antara dua nilai } \\
\text { berdekatan }\end{array}$} \\
\hline \multicolumn{4}{|c|}{ Sumber: Saaty (1983), Marimin dan Maghfiroh (2010) } \\
\hline \multicolumn{4}{|c|}{ Tabel 2. Indikator rawan banjir. } \\
\hline $\begin{array}{c}\text { Indikator/ } \\
\text { Bobot }\end{array}$ & Sub. Indikator & Harkat & Skor \\
\hline \multirow[t]{7}{*}{ Jenis Tanah (5) } & $\begin{array}{l}\text { Dystric cambisols, haplic } \\
\text { acrisols }\end{array}$ & 5 & 25 \\
\hline & Haplic acrisols & 4 & 20 \\
\hline & $\begin{array}{l}\text { Haplic acrisols, dystric } \\
\text { cambisols }\end{array}$ & 4 & 20 \\
\hline & $\begin{array}{l}\text { Dystric nitrosols, rhodic } \\
\text { ferralsols, dystric } \\
\text { cambisols }\end{array}$ & 3 & 15 \\
\hline & $\begin{array}{l}\text { Umbric andosols, humic } \\
\text { cambisols }\end{array}$ & 3 & 15 \\
\hline & $\begin{array}{l}\text { Dystric cambisols, dystric } \\
\text { geysols }\end{array}$ & 2 & 10 \\
\hline & $\begin{array}{l}\text { Dystric cambisols,ferric } \\
\text { acrisols }\end{array}$ & 1 & 5 \\
\hline \multirow{5}{*}{$\begin{array}{l}\text { Lereng (\%) } \\
(20)\end{array}$} & $0-8$ & 5 & 100 \\
\hline & $8-16$ & 4 & 80 \\
\hline & $16-27$ & 3 & 60 \\
\hline & $27-40$ & 2 & 40 \\
\hline & $>40$ & 1 & 20 \\
\hline \multirow[t]{5}{*}{$\begin{array}{l}\text { Bentuklahan } \\
\text { (15) }\end{array}$} & Fluvial & 5 & 75 \\
\hline & Karst & 4 & 60 \\
\hline & Struktural & 3 & 45 \\
\hline & Vulkanik & 2 & 30 \\
\hline & Denudasional & 1 & 15 \\
\hline \multirow[t]{6}{*}{$\begin{array}{l}\text { Curah Hujan } \\
\text { (15) }\end{array}$} & $>5000$ & 6 & 90 \\
\hline & $4500-5000$ & 5 & 75 \\
\hline & $4000-4500$ & 4 & 60 \\
\hline & $3500-4000$ & 3 & 45 \\
\hline & $3000-3500$ & 2 & 30 \\
\hline & $2500-3000$ & 1 & 15 \\
\hline \multirow{5}{*}{$\begin{array}{l}\text { Elevasi Sungai } \\
\text { (15) }\end{array}$} & $0-5$ meter & 5 & 75 \\
\hline & $10-15$ meter & 4 & 60 \\
\hline & $15-20$ meter & 3 & 45 \\
\hline & $20-25$ meter & 2 & 30 \\
\hline & $>25$ meter & 1 & 15 \\
\hline Penggunaan & Permukiman & 5 & 50 \\
\hline \multirow[t]{5}{*}{ Lahan (10) } & Sawah & 4 & 40 \\
\hline & Lahan kosong & 4 & 40 \\
\hline & Kebun campuran & 3 & 30 \\
\hline & Semak belukar & 2 & 20 \\
\hline & Hutan & 1 & 10 \\
\hline \multirow[t]{9}{*}{ Geologi (5) } & Aluvium (Qh) & 5 & 25 \\
\hline & Batu apung tufa (Qpt) & 4 & 20 \\
\hline & $\begin{array}{l}\text { Batu kuasa campur batu } \\
\text { lanau (Tms) }\end{array}$ & 4 & 20 \\
\hline & Batu andesit (Qvmt) & 3 & 15 \\
\hline & Batu gamping (TLs) & 3 & 15 \\
\hline & Batu bara (MLt) & 2 & 10 \\
\hline & $\begin{array}{l}\text { Batu sabak campur kuarsa } \\
\text { (PCks) }\end{array}$ & 2 & 10 \\
\hline & $\begin{array}{l}\text { Batu filit, kuarsa campur } \\
\text { batu lanau (pTps) }\end{array}$ & 1 & 5 \\
\hline & Batu vulkanik (Tmv) & 1 & 5 \\
\hline
\end{tabular}
pada Gambar 2.

Tabel 3. Kelas Interval Rawan Banjir.

\begin{tabular}{ccc}
\hline Kelas Kerawanan & $\begin{array}{c}\text { Kelas } \\
\text { Interval }\end{array}$ & Indeks Kerawanan \\
\hline Kelas Rendah & $85-203$ & Zona Rawan Rendah \\
Kelas sedang & $204-321$ & Zona Rawan Sedang \\
Kelas tinggi & $322-440$ & Zona Rawan Tinggi \\
\hline Sumber: Umar (2016) & &
\end{tabular}

Tabel 4. Kriteria penilaian dalam AHP 


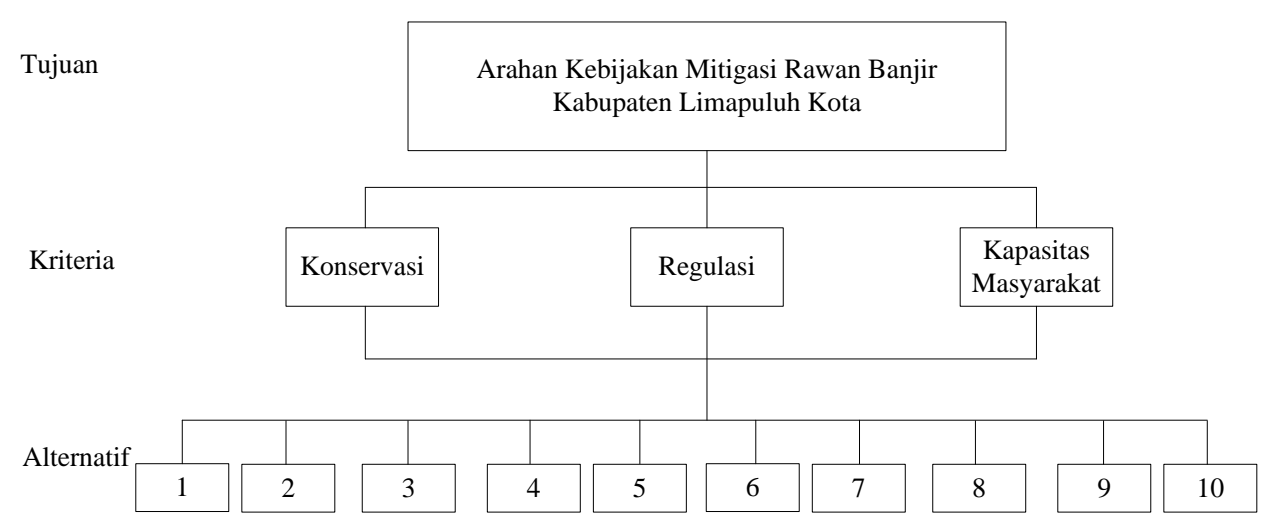

Keterangan:

1. Melakukan reboisasi

2. Pencegarah penebangan hutan

3. Pemanfaatan lahan secara terasering

4. Selektif dalam mengeluarkan IMB pada zona rawan banjir

5. Pembongkaran bangunan liar

6. Pembuatan RTRW lebih rinci

7. Peningkatan sosialisasi pada zona rawan banjir

8. Relokasi permukiman pada zona rawan banjir

9. Pendidikan kebencanaan

10. Perencanaan ruang berbasis bencana

Gambar 2. Struktur hierarki arahan kebijakan mitigasi rawan banjir

\section{Hasil dan Pembahasan}

Bencana banjir di Kabupaten Limapuluh Kota periode 2010-2017 telah terjadi peningkatan frekuensi kejadian dan luasan wilayah yang terkena dampak bencana banjir. Bencana banjir pada bulan Februari 2017 telah merendam sekitar 1,000 ha sawah dan 4.000 rumah (BPBD Kab. Limapuluh Kota (2017). Asdak (1995) menyatakan tiga faktor utama penyebab banjir pada suatu wilayah, yaitu: tingginya intensitas curah hujan dalam waktu yang lama, karakteristik daerah aliran sungai (DAS), dan perilaku masyarakat sekitar DAS.

Data curah hujan pada Kabupaten Lamapuluh Kota periode 1975-2017 berdasarkan stasiun penangkap curah hujan menunjukkan adanya kecenderuangan mengalami peningkatan selama 10 tahun belakangan (BMKG Sicincin, 2017). Mudelsee et al. (2003) menyatakan bahwa terjadinya peningkatan curah hujan dibanyak wilayah akibat pengaruh efek radiasi GRK. Peningkatan radiasi GRK disebabkan faktor antropogegik, seperti pengurangan kawasan hutan.

Penggunaan lahan di Kabupaten Limapuluh Kota periode 1989-2016 berdasarkan analisis citra Landsat ETM+7 tahun 1989 dan citra Landsat ETM+7 tahun 2016 telah terjadi pengurangan kawasan hutan primer sekitar 30\%. Kodra dan Syaurkani (2004) menyatakan bahwa hutan memiliki peran penting dalam menjaga tata air tanah dan daur hidrologi. Yuksek et al. (2013) menyatakan dampak konversi kawasan hujan menjadi penggunaan lain adalah terjadinya peningkatan bencana banjir. Penning Rowsell (2003) dan Umar et al. (2016b) menyatakan selain faktor konversi kawasan hutan menjadi pengunaan lain, tidak terkontrolnya pemanfaatan hutan sepanjang aliran sungai juga sebagai penyebab terjadinya peningkatan bencana banjir.

Suripin (2004) dan Umar (2016a) mengungkapkan bahwa faktor kemiringan lereng berkorelasi positif terhadap bencana banjir. Wilayah yang relatif datar $(0-$ $8 \%$ ) akan lebih sering mengalami banjir dibandingkan wilayah yang agak bergelobang sampai terjal. Selain itu, wilayah yang datar endapan sedimentasi menyebabkan pendangkalan sungai, sehingga akan terjadi luapan air sungai. Kabupaten Lima Puluh Kota memiliki sekitar $20 \%$ wilayah dengan kemiringan lereng $0-8 \%$ (datar).

Hasil analisis tingkat kerawanan banjir di Kabupaten Limapuluh Kota, sekitar $6.2 \%$ memiliki tingkat kerawanan tinggi, 54\% rawan sedang, dan 38.8\% merupakan zona aman terhadap banjir. Selanjutnya, bila dibandingkan dengan penggunaan lahan kawasan permukiman sekitar 27\% masuk pada kategori sangat rawan. Gambar 3 disajikan zona rawan banjir di Kabupaten Limapuluh Kota. 


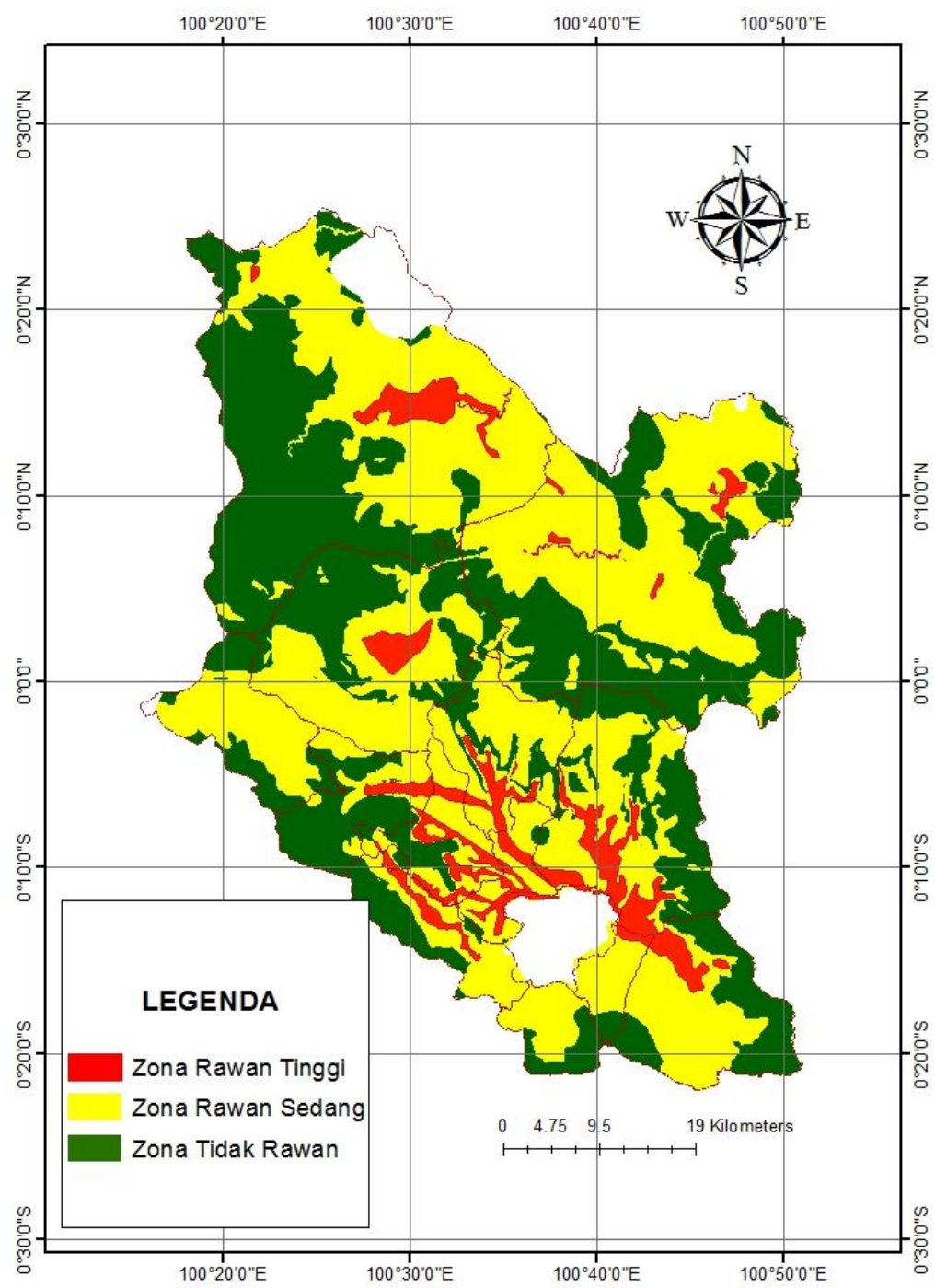

Gambar 3. Peta zona rawan banjir Kabupaten Limapuluh Kota

Secara demografis Kabupaten Limapuluh Kota memiliki angka pertumbuhan penduduk sebesar $1.9 \%$ per tahun. Sadyohutomo (2008) dan Mutaáli (2012) menyatakan bahwa pertumbuhan penduduk yang tinggi pada suatu wilayah akan menciptakan konflik antar penggunaan lahan. Kaur et al. (2004) dan Pribadi et al. (2007) menambahkan pertumbuhan penduduk yang tinggi akan menyebabkan pergeseran fungsi ekologis ruang, ruang terbangun lebih mondominasi dan mendesak ruang alami untuk berubah fungsi. Perubahan fungsi ekologis ruang akan akan menyebabkan berkurangnya kemampuan lahan untuk menyerap air saat musim penghujan.
Gambar 4 merupakan hasil analisis AHP tentang arahan kebijakan mitigasi banjir Kabupaten Limapuluh Kota. Nilai inconsistency ratio (CR) pendapat pakar sebesar 0,04. Marimin dan Maghfiroh (2010) nilai inconsistency ratio yang dapat diterima adalah kurang dari 0,1 .

UU No 24 Tahun 2007 tentang penanggulangan bencana menyatakan mitigasi adalah serangkaian upaya untuk mengurangi risiko bencana. Berdasarkan hasil analisis menunjukkan bahwa terdapat tiga alternatif utama arahan kebijakan mitigasi rawan banjir, yaitu: pendidikan kebencanaan, peningkatan sosialisasi pada zona rawan banjir, dan perencanaan ruang berbasis bencana. 
Sunthesis with respect to:

Goal: Arahan Kebiiakan Mitiqasi Baniir Kab. Limapuluh Kota

0 verall Inconsistenos $=, 04$

Melakukan reboisasi
Pencegahan penebanqan hutan
Pem anfaatan lahan secara ter asering
Selektif dalam penqeluar an IMB pada zona rawan banii
Pem bonqkaran banqunan liar
Pembuatan RTRW lebih rinci
Peninqkatan sosialisasi pada zona rawan baniir
Relokasi permukiman pada zona rawan baniir
Pendidikan kebencanaan
Perencanaan ruanq berbasis bencana

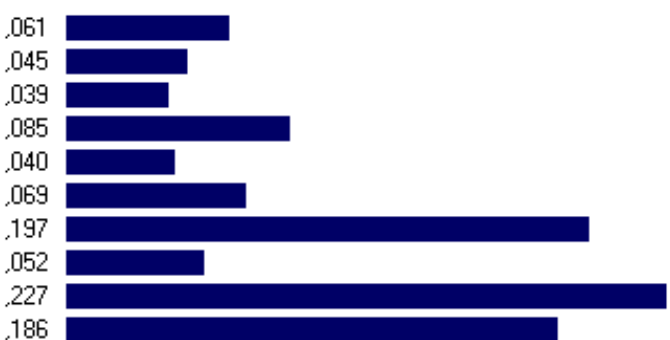

Gambar 4. Hasil analisis AHP tentang arahan kebijakan mitigasi Kab. Limapuluh Kota

Stoica dan Iancu (2011) menyatakan salah satu upaya untuk mengurangi dampak risiko bencana dengan jalan meningkatkan kapasitas masyarakat dalam menghadapi bencana. BNPB (2012) menjelaskan pendidikan kebencanaan dan peningkatan sosialisasi pada zona rawan bencana merupakan indikator meningkatkan kapasitas masyarakat dalam mengurangi risiko bencana.

Peningkatan kapasitas masyarakat dalam mengurangi risiko banjir dapat diimplentasikan dengan cara memasukan pendidikan kebencanaan pada kurikulum sekolah. Dengan memasukan pendidikan kebencanaan pada wilayah rawan bencana merupakan upaya efektif mengurangi risiko akibat bencana. Kanreuther (2008) menyatakan memasukan pendidikan kebencanaan pada semua elemen masyarakat dapat mengurangi 40-60\% kerugian akibat bencana.

Selain itu, Suripin (2004), El-Kadi dan Yamashita (2007), dan Umar (2016a) mengemukakan bahwa salah satu solusi untuk mitigasi kawasan rawan banjir dengan cara memasukan unsur kebencanaan dalam penyusunan tata ruang. Hal ini sesuai sesuai dengan arahan kebijakan mitigasi bencana dengan memasukan perencanaan ruang berbasis bencana.

\section{Kesimpulan}

Kabupaten Limapuluh Kota bencana banjir mengalami peningkatan dari frekunsi kejadian dan luasan daerah mengalami banjir. Tingginya intensitas curah hujan dan konversi kawasan hutan menjadi penggunaan lain sebagai faktor penyebab banjir. Sekitar $6.2 \%$ wilayah Kabupaten Limapuluh Kota merupakan zona tingkat kerawan tinggi terhadap bencana banjir. Kawasan permukiman yang terbangun pada zona rawan tinggi sekitar $27 \%$. Upaya mitigasi mengurangi risiko banjir maka terdapat tiga arahan kebijakan, yaitu: pendidikan kebencanaan, peningkatan sosialisasi pada zona rawan banjir, dan perencanaan ruang berbasis bencana.

Kepada pemerintah Kabupaten Limapuluh Kota agar memasukan kurikulum pendidikan kebencanaan mulai tingkat dasar sampai sekolah menengah, melakukan sosialisasi pada zona rawan bencana, dan melakukan perencanaan ruang berbasis kebencanaan.

\section{Ucapan Terimakasih}

Kepada Program Doktor Ilmu Lingkungan Pascasarjana dan PKLH UNP yang telah mensposori penelitian ini dan Bappeda Kabupaten Limapuluh Kota yang telah menfasilitasi penelitian.

\section{Daftar Pustaka}

[1] Asdak, C., 1995. Hidrologi dan Pengelolaan DaerahAliran Sungai. Percetakan Gadjah Mada University . Yogyakarta

[2] Bechtol V, Laurian L. 2005. Restoring Straightened Rivers for Sustainable Flood Mitigation. Disaster Prevention and Management. 14(1), pp, 6-19.

[3] [BMKG] Badan Meteorologi Klimatologi dan Geofisika Sicincin, 2017. Data curah hujan periode 1975-2017. BMKG Sicincin, Sicincin.

[4] [BNPB] Badan Nasional Penanggulangan Bencana. edoman Umum Penanggulangan Resiko Bencana, Jakarta.

[5] [BPBD] Badan Penanggulangan Bencana Daerah Kabupaten Limapuluh Kota, 2017. Catatan Kebencanaan Daerah. BPBD Kab. Limapuluh Kota, Limapuluh Kota.

[6] El-Kadi, A., E. Yamashita, 2007. Modeling Streamflows and Flood Delineation of the 2004 Flood Disaster. Manoa, O'ahu, hawai'i1. Pacific Science. 61(2), pp. 235-238.

[7] Gharagozlou, A., H. Nazari, M. Seddighi, 2011. Spatial Analysis for Flood Control by Using Environmental Modeling. Journal of Geographic Information System, 3(4), pp. 367-372.

[8] Karmakar, S., S. Simonovic, A. Peck, J. Black, 2010. An Information System for Risk-Vulnerability Assessment to Flood. Journal of Geographic Information System. 2(3), pp. 129-146.

[9] Kaur, E., H. Palang, H. Soovali, 2004. Landscapes in ChangeOpposing Attitudes in Saaremaa, Estonia. Landscape and Urban Planning. 67, pp. 109-120.

[10] Kodra, H.S.A., dan Syaurkani., 2004. Bumi Makin Panas Banjir Makin Luas. Penerbit Yayasan Nuasa Cendikia, Bandung.

[11] Kodoatie, R., 2013. Rekayasa dan Banjir Kota. Penerbit ANDI, Yogyakarta.

[12] Kunreuther, H., 2008. Reducing Losses from Catastrophic Risks Through Long term Insurance and Mitigation. Social Research. 75(3), pp. 905-930.

[13] Marimin, dan Maghfiroh, N., 2010. Aplikasi Teknik Pengambil Keputusan dalam Manajemen Rantai Pasok. IPB Press, Bogor. 
[14] Mudelsee, M., M. Borngen, G. Tetzlaff, U. Grunewald, 2003 No Upward Trends in The Occurrence of Extreme Floods in Central Europe. Nature, 425(6954), pp. 1-9.

[15] Muta'ali, L., 2012. Daya Dukung Lingkungan untuk Perencanaan Pengembangan Wilayah. Badan Penerbit Fakultas Geografi (BPFG) Universitas Gadjah Mada, Yoyakarta.

[16] Penning-Rowsell, E., 2003. Flood Hazard Response in Argentina. Geographical Review. 86(1), pp. 72-90.

[17] Popovska, C., M. Jovanovski, D. Ivanoski, I. Pesevski, 2010. Storm Sewer System Analysis In Urban Areas and Flood Risk Assessment. Technical University of Civil Engineering from Bucharest.75(3), pp. 95-110.

[18] Pribadi, D., D. Shiddiq, M. Ermyanila, 2006. Model Perubahan Tutupan Lahan dan Faktor-Faktor yang Mempengaruhinya. Jurnal Teknologi Lingkungan BPPT. 3 (1), pp. 77-91.

[19] [RI] Republik Indonesia, 2007. Undang-Undang No 24 Tahun 2007 tentang Penanggulangan Bencana. Lembaran Negara RI Tahun 2007, No 68. Sekretariat Negara, Jakarta.

[20] Stoica, A., I. Iancu, 2011. Flood Vulnerability Assesment Based on Mathematical Modeling. Technical University of Civil Engineering from Bucharest. 425(69), pp. 1-9.
[21] Suripin, 2004. Sistem Drainase Perkotaan yang Berkelanjutan. Penerbit ANDI, Yogyakarta.

[22] Sadyohutomo, M., 2008. Manajemen Kota dan Wilayah Realitas dan Tantangan. Penerbit Bumi Aksara, Jakarta.

[23] Umar, I., 2016a. Mitigasi Bencana Banjir pada Kawasan Permukimann Di Kota Padang (disertasi). Bogor, Sekolah Pascasarjana IPB.

[24] Umar, I., Widiatmaka, B. Pramudya, dan B. Barus, 2006b. Delineation of Flood Harzad Zones by Using a Multi Criteria Evaluation Approach in Padang West Sumatera Indonesia. Journal of Enviroment and Earh Science. 4(3), pp. 27-34.

[25] Wardhono, A., G. Pratomo, B. Prakoso, C. Qori'ah, 2012. Countermeasures Flood Disaster Sampean River Policy in Situbondo District. Journal of Law and Social Sciences (JLSS). 2(1), pp. 118-122.

[26] Yang, M., X. Qian, Y. Zhang, J. Sheng, D. Shen, Y. Ge, 2011 Spatial Multicriteria Decision Analysis of Flood Risks in Aging-Dam Management in China. International Journal of Environmental Research and Public Health. 8(5), pp. 13681387.

[27] Yüksek, O., M. Kankal, O. Üçüncü, 2013. Assessment of Big Floods in the Eastern Black Sea Basin of Turkey. Environmental Monitoring and Assessment. 185(1), pp. 797814. 